JEVTE: Journal of Electrical Vocational Teacher Education, Vol. 1, No. 1, Mei 2021

\title{
PENGEMBANGAN MEDIA PEMBELAJARAN MOBILE LEARNING BERBASIS ANDROID DENGAN ISPRING SUITE PADA MATA PELAJARAN INSTALASI MOTOR LISTRIK KELAS XI JURUSAN TEKNIK INSTALASI TENAGA LISTRIK DI SMK SWASTA IMELDA MEDAN
}

\author{
Rico Faul Yohannes Sinaga ${ }^{1}$, Nelson Sinaga ${ }^{2}$ \\ Fakultas Teknik, Universitas Negeri Medan \\ ricosinaga23@gmail.com
}

\begin{abstract}
Development of Android-based Mobile Learning Media with Ispring Suite in Electrical Motor Installation Subjects Class XI Department of Electrical Installation Engineering at Imelda Private Vocational School Medan, 2020. This study aims to find out the design of a media Development of Android-based Mobile Learning Media with Ispring Suite in Electrical Motor Installation Subjects Class XI Department of Electrical Installation Engineering at Imelda Private Vocational School Medan and test the feasibility of Android-based Mobile Learning learning media designed as a learning medium for students. This research was conducted on grade XI students of TITL SMK Swasta Imelda Medan in the 2019/2020 school year. This research was tested to lecturers and teachers. The procedure of developing Android-based learning media in the subjects of installing a simple building electric motor installation packaged in the form of interactive softcopy/CD software is carried out using the $R \& D$ method of ADDIE development design. As well as the media feasibility validation processAbstract must reflect the overall substance of the article content and be able to help readers determine its relevance to their interests and decide whether to read the document in its entirety, esearchers use the ADDlE method in research and development. The results of this study showed the validation of the poll of media experts with an average of 4.20 interpretations is very good and very worthy to be used as a medium of learning. Validation of material experts (content experts) with an average of 4.72 interpretations is very well used as a medium of learning. User validation with an average of 4.16 interpretations is very good and very worthy to be used as a learning medium.
\end{abstract}

Key Words: Development, Learning Media, Electrical Motor Installation

\begin{abstract}
Abstrak
Pengembangan Media Pembelajaran Mobile Learning Berbasis Android dengan Ispring Suite pada Mata Pelajaran Instalasi Motor Listrik Kelas XI Jurusan Teknik Instalasi Tenaga Listrik di SMK Swasta Imelda Medan, 2020. Penelitian ini bertujuan untuk mengetahui rancangan sebuah media Pengembangan Media Pembelajaran Mobile Learning Berbasis Android dengan Ispring Suite pada Mata Pelajaran Instalasi Motor Listrik Kelas XI Jurusan Teknik Instalasi Tenaga Listrik di SMK Swasta Imelda Medan dan menguji kelayakan media pembelajaran Mobile Learning berbasis Android yang dirancang sebagai media pembelajaran bagi siswa. Penelitian ini dilakukan pada siswa kelas XI TITL SMK Swasta Imelda Medan tahun ajaran 2019/2020. Penelitian ini diuji cobakan kepada Dosen dan Guru. Prosedur pengembangan media pembelajaran berbasis Android pada mata pelajaran memasang instalasi motor listrik bangunan sederhana yang dikemas dalam bentuk software softcopy/CD interaktif dilakukan dengan menggunakan metode R\&D desain pengembangan ADDIE. Serta proses validasi kelayakan media, peneliti menggunakan metode $A D D l E$ dalam penelitian dan pengembangan (Research and Development). Hasil penelitian ini menunjukkan validasi angket ahli media dengan rata-rata 4,20 interpretasi sangat baik dan sangat layak digunakan sebagai media pemebelajaran. Validasi ahli materi (pakar konten) dengan rata-rata 4,72 interpretasi sangat baik digunakan sebagai media pembelajaran. Validasi user dengan rata-rata 4,16 interpretasi sangat baik dan sangat layak digunakan sebagai media pembelajaran.
\end{abstract}

Kata Kunci: : Pengembangan, Media Pembelajaran, Instalasi Motor Listrik 


\section{PENDAHULUAN}

Pada Hakekat nya Pendidikan merupakan aspek yang dapat membentuk sumber daya manusia yang bermanfaat bagi kehidupan. Oleh karena itu, pendidikan harus dilaksanakan dengan sebaik-baiknya, sehingga tujuan untuk mencapai keberhasilan suatu bangsa dapat terwujud. Pendidikan merupakan hal yang sudah melekat pada kehidupan manusia. Pendidikan sudah menjadi kebutuhan pokok untuk memenuhi kehidupan manusia dimasa yang akan datang Menurut Yudhi Munadi (2008:3) pendidikan merupakan suatu peistiwa yang memiliki norma. Peristiwa tersebut adalah satu rangkaian kegiatan komunikasi antar manusia, yaitu rangkaian yang saling mempengaruhi dimana terdapat satu rangkaian proses perubahan dan penumbuh kembang fungsi jasmaniah, penumbuh-kembangan watak, intelek dan sosial. Dengan demikian, pendidikan dapat digunakan sebagai perencanaan kehidupan manusia. Pendidikan harus dilaksanakan dengan sebaik-baiknya sehingga tujuan pendidikan dapat terwujud untuk memajukan suatu bangsa.

Saat ini guru profesional dituntut mampu menggunakan berbagai media pembelajaran yang ada disekitarnya. Menurut Yudhi Munadi (2008:1) untuk mewujudkan pendidikan yang berkualitas, salah satu yang harus ada adalah guru yang berkualitas. Guru yang berkualitas ini adalah guru yang memiliki kemampuan untuk mewujudkan tujuan pendidikan nasioal, yakni yang memiliki kompetensi pedagogik, kompetensi kepribadian, kompetensi sosial, dan kompetensi profesional (UU RI No.14 Tahun 2005 tentang Guru dan Dosen). Misalnya, dalam melaksanakan kompetensi pedagogik,guru dituntut memiliki kemampuan secara metodologis dalam hal perancangan dan pelaksanaan pembelajaran. Termasuk didalamnya penguasaan dalam penggunaan media pembelajaran. Demikian dengan guru SMK khususnya guru pendidikan teknik elektro harus mampu menggunakan media pembelajaran dalam proses pembelajaran. Dalam hal ini proses pembelajaran juga membutuhkan peran multimedia agar dapat memberikan dorongan, dan pengarahan kepada siswa Dengan peran multimedia dalam proses pembelajaran yang tepat, siswa dapat mudah memahami materi pembelajaran.

Perkembangan ilmu pengetahuan dan teknologi mendorong proses pembelajaran untuk lebih aplikatif dan menarik sebagai upaya untuk peningkatan kualitas pendidikan. Inovasi dan metode pengajaran yang baru dan tepat akan membantu proses pemahaman siswa sehingga siswa dapat mengaplikasikan ilmu yang diperoleh dalam kehidupan sehari-hari. Salah satu cara untuk mendorong tercapainya pembelajaran yang efektif, digunakanlah alat bantu belajar atau yang biasa disebut media.

Dalam Media pendidikan oleh Commission on Instructional Technolgy (1970) diartikan sebagai media yang lahir sebagai akibat revolusi komunikasi yang dapat digunakan untuk tujuan pembelajaran disamping guru, buku, teks, papan tulis. Gagne (1970) mengatakan bahwa media pendidikan adalah berbagai jenis komponen dalam lingkungan siswa yang dapat merangsang siswa untuk belajara (Yusufhadi Miarso, 2019:457).Menurut Hamalik dalam Rusman (2013: 164) fungsi media dalam pembelajaran yaitu untuk mewujudkan situasi pembelajaran yang efektif, mempercepat proses pembelajaran dan membantu siswa dalam upaya memahami materi yang disajikan oleh guru serta untuk mempertinggi mutu pendidikan. Media dalam pendidikan juga merupakan suatu alat atau perantara yang berguna untuk memudahkan proses belajar mengajar, dalam rangka mengefektifkan komunikasi antara guru dan siswa. Hal ini sangat membantu guru dalam mengajar dan memudahkan siswa menerima dan memahami pelajaran. Proses ini membutuhkan guru yang mampu menyelaraskan antara media pembelajaran dan metode pembelajaran. Pemakaian media pembelajaran dalam proses belajar mengajar juga dapat membangkitkan keinginan dan minat yang baru bagi siswa, membangkitkan motivasi belajar, dan bahkan membawa pengaruh psikologis terhadap siswa. Selain dapat meningkatkan motivasi belajar siswa, pemakaian atau pemanfaatan media juga dapat meningkatkan pemahaman siswa terhadap pelajaran.

Di indonesia media pembelajaran yang digunakan di sekolah adalah power point, video pembelajaran, LKS (modul), dan media gambar. Media pembelajaran tersebut tidak bisa sewaktuwaktu digunakan oleh siswa (kurang praktis). Ketersediaan perpustakaan yang sudah memuat berbagai referensi bukupun masih belum menimbulkan minat siswa dalam membaca. Pemanfaatan media pembelajaran sedapat mungkin dapat diterapkan disemua mata pelajaran, termasuk dalam mata pelajaran Intsalasi Motor Listrik.

Hal ini yang mengharuskan proses pembelajaran harus dikemas semenarik mungkin salah satunya dengan menggunakan media pembelajaran yang inovatif sehingga siswa bisa berlama-lama mempelajari suatu materi. Media pembelajaran saat ini sudah banyak dikembangkan, namun masih sering pendidik yang merasakan media tersebut terlalu rumit dan banyak memakan waktu dalam proses pembuatannya, selain itu tidak mampu bertahan lama media tersebut. Selain itu media pembelajaran Instlasi Motor 
Listrik menggunakan gambar dinilai kurang praktis dibawa. Sehingga hal tersebut membuat guru jarang sekali memakai media pembelajaran gambar. Kurang variatifnya media yang dibagikan bukan sematamata kesalahan guru, namun karena kurang mengoptimalkan perkembangan teknologi.

Perkembangan teknologi mobile saat ini begitu pesat, salah satu perangkat mobile yang saat ini sudah umum digunakan adalah telepon seluler. Hampir $90 \%$ siswa pasti sudah mempunyai satu telepon seluler atau bahkan ada yang mempunyai lebih dari satu telepon seluler. Semakin banyaknya siswa yang memiliki dan menggunakan perangkat mobile maka semakin besar pula peluang penggunaan perangkat teknologi dalam dunia pendidikan. Media pembelajaran yang memanfaatkan teknologi telepon seluler disebut dengan mobile learning. Mobile learning merupakan salah satu alternatif pengembangan media pembelajaran.

Berdasarkan data yang di temukan oleh Hootsuite, jumlah pengguna ponsel di Indonesia pada januari 2018, menembus angka 177,9 juta pengguna atau sebesar 67\%. Sementara pengguna akses internet melalui smartphone sebesar 132 juta. Seiring dengan bertambahnya tahun, maka pengguna smartphone juga akan semakin meningkat.

Android merupakan sistem operasi berbasis Linux yang dirancang untuk perangkat bergerak layar sentuh seperti telepon pintar dan komputer tablet (Wikipedia,2019). Android tidak terlepas dari sifatnya yang terbuka sehingga memudahkan penggunanya untuk mengakses berbagai aplikasi dengan gratis maupun berbayar. Saat ini sudah banyak aplikasi yang disediakan Play Store yang dengan mudah pengguna mengunduhnya ke dalam smartphone. Namun, sampai saat ini masih sedikit aplikasi media pembelajaran tentang Instalasi Motor Listrik yang tersedia di Play Store.

Berdasarkan hasil observasi di SMK Swasta Imelda Medan bahwa mata pelajaran Instalasi Motor Listrik, masih sukar dipahami para siswa karena pembelajaran yang hanya menjelaskan secara teoritik, tidak interaktif dan kurang mengoptimalkan teknologi dalam media pembelajaran. Guru masih menerapkan proses belajar secara konvensional dimana hanya berpusat pada guru. Yang mempengaruhi pemahaman siswa saat belajar dan berdasarkan banyak penelitian yang telah dilakukan menggunakan media Maka, media pembelajaran yang interaktif perlu dikembangkan oleh guru agar dapat meningkatkan pemahaman siswa terhadap materi yang disampaikan dalam mata pelajaran Instalasi Motor Listrik.

Hasil Observasi yang telah di lakukan penulis juga melihat sebagian besar siswa SMK Swasta Imelda Medan sudah menggunakan smartphone Android. Namun, hanya sedikit siswa yang menggunakan smartphone untuk belajar. Siswa cenderung menggunakan smartphone hanya untuk bermain game dan sosial media seperti instagram, facebook, line, Whatsapp ,dan sebagainya. Pembelajaran yang dilakukan Masih melalui media konvensional seperti papan tulis, Powerpoint dan Jobseet. Sehingga mempengaruhi pemahaman siswa terhadap pembelajaran instalasi motor listrik.

Materi memahami macam macam pengendali motor listrik, dan memahami prinsip kerja komponen pengendali motor listrik serta memahami gambar instalasi motor lisrik dengan kendali elektromagnetik merupakan materi yang penting pada mata pelajaran Instalasi Motor Listrik dengan menggunakan media masih cenderung rendah. Rendahnya disebabkan guru kurang mengoptimalkan media berupa animasi sehingga peserta didik menjadi kurang memahami dan tertarik pada materi Instalasi Motor Listrik. Kurangnya pemahaman siswa tersebut menyebabkan hasil belajar siswa kurang memuaskan.

Berdasarkan uraian diatas, maka penulis melakukan penelitian yaitu " Pengembangan Media Pembelajaran Mobile Learning Berbasis Android dengan Ispring Suite 8 pada Mata Pelajaran Instalasi Motor Listrik Kelas XI Jurusan Teknik Instalasi Tenaga Listrik di SMK Swasta Imelda Medan" Tahun 2020/2021.

Berdasarkan latar belakang, maka rumusan masalah yang ada akan dijawab dalam penelitian meliputi (1) Bagaimana pengembangan media pembelajaran mobile learning berbasis android dengan Ispring suite 8 pada mata pelajaran instalasi motor listrik untuk siswa kelas XI TITL SMK Swasta Imelda Medan? (2) Bagaimana kelayakan produk media pembelajaran mobile learning berbasis android dengan Ispring suite 8 untuk mata pelajaran instalasi motor listrik untuk siswa kelas XI TITL SMK Swasta Imelda Medan?

\section{METODE}

Metode penelitian adalah prosedur secara ilmimah untuk mendapatkan data sehingga memenuhi tujuan penelitian. Metode penelitian pada penelitian ini menggunakan Research and Development (R\&D). Penelitian ini bertujuan untuk menghasilkan produk baru melalui proses pengembangan ( Endang Mulyatiningsih, 2011: 162 ). Hal ini sesuai dengan tujuan penelitian yaitu untuk dapat 
mengembangkan media pembelajaran mobile learning berbasis android untuk mempermudah mata pelajaran instalasi motor listrik untuk siswa kelas XI TITL SMK Swasta Imelda Medan.

Prosedur Pengembangan Media Model pengembangan produk ini adalah serangkaian prosedur rangka menghasilkan media pembelajaran mobile learning berbasis android pada mata pelajaran Instalasi Motor Listrik untuk siswa menengah kejuruan XI TITL. Model pengembangan produk ini menggunakan model ADDIE. Adapun langkah-langkah yang akan dilakukan pada tahapan pelaksanaan penelitian model ADDIE adalah sebagai berikut: (1) Tahap Analisis (Analysis) Berdasarkan permasalahan yang ada, maka peneliti melakukan analisis melalui wawancara, studi literature, dan browsing internet. Hal ini dilakukan untuk mengetahui karakteristik kebutuhan siswa yang akan menjadi sasaran pengguna mobile learning berbasis android. Sehingga dengan hasil analisis tersebut diharapkan akan meningkatkan kebermanfaat produk yang akan dibuat nanti sesuai dengan karakteristik pengguna pada masa sekarang. Analisis kompetensi dan intruksional yang meliputi analisis terhadap Kompetensi yang perlu di pelajari siswa. Pada kesempatan kali ini akan dibahas mengenai materi memahami macam macam pengendali motor listrik, memahami prinsip kerja komponen pengendali motor listrik serta memahami gambar instalasi motor lisrik dengan kendali elektromagnetik

Untuk memenuhi tahap ini, penulis menentukan materi-materi yang akan dibuat dalam media pembelajaran mobile learning berbasis android untuk meningkatkan kinerja/prestasi siswa SMK. (2) Tahap Desain (Design) Desain bertujuan untuk menentukan spesifikasi detil dari komponen komponen sistem informasi dan produk informasi yang sesuai dengan analisis. Berdasarkan hasil analisis, tahap yang selanjutnya yaitu desain produk yang meliputi : (a) Menetapkan Materi Pada tahap ini dikemukanan dasar pemilihan mata pelajaran Instalasi Motor Listrik mengenai materi Motor Listrik. Instalasi Motor Listrik dipilih karena sesuai dengan kompetensi penulis. Materi Motor Listrik ini yaitu tentang materi memahami macam macam pengendali motor listrik, memahami prinsip kerja komponen pengendali motor listrik serta memahami gambar instalasi motor lisrik dengan kendali elektromagnetik. (b) Pengumpulan background dan gambar Pengumpulan background dan gambar adalah dengan mengunduh dari situs penyedia gambar yaitu google kemudian dibuat dalam format .png (portable network graphics) dengan menggunakan aplikasi Paint. (c) Pembuatan Desain Media Pembelajaran Storyboard merupakan gambaran media pembelajaran secara keseluruhan yang akan dimuat dalam aplikasi. Storyboard berfungsi sebagai panduan seperti peta untuk memudahkan proses pembuatan media. Dalam hal ini peneliti melihat tutorial pembuatan aplikasi pada channel youtube dari Nairotecho Channel. (3). Tahap Pengembangan (Development) (a) Membuat Produk Media Pembelajaran Berbasis Android Produk media pembelajaran dibuat sesuai dengan format yang sudah ditentukan sebelumnya yaitu menggunakan software Ispring Suite. (b) Validasi Ahli Materi dan Ahli Media.

Setelah tahap pengembangan desain telah selesai, selanjutnya yang akan dilakukan adalah melakukan pengujian terhadap produk untuk tahap pengembangan produk. Kegiatan validasi produk yang berupa media interaktif berbasis android divalidasi oleh 2 orang reviewer ahli media dan 2 reviewer ahli materi, hal ini juga dimaksudkan untuk mendapatkan masukan-masukan maupun koreksi tentang produk yang telah dikembangkan. (4). Tahap Implementasi (Implementation) Tahap implementasi ini produk akan diuji cobakan kepada 30 siswa SMK kelas XI TITL. Pada tahap ini juga dibagikan angket untuk mengukur dan mengetahui pendapat atau respon peserta didik mengenai media pembelajaran berupa aplikasi android untuk mata pembelajaran Motor Listrik. Bila diperlukan maka akan dilakukan revisi berdasarkan masukan dan saran dari siswa. Namun, dalam revisi ini akan dipertimbangkan masukan dan saran dari validator sebelumnya agar tidak bertentangan dengan perbaikan-perbaikan sebelumnya. (5). Tahap Evaluasi (Evaluation) Pada tahap evaluasi, kegiatan yang dilakukan merupakan evaluasi terhadap setiap proses pengembangan media untuk memvalidasi produk. Pada proses evaluasi, media hasil penelitian mendapatkan penilaian kualitas yang bertujuan untuk memastikan keberhasilan dan kelayakan media. Kegiatan evaluasi produk dilakukan oleh 2 orang reviewer ahli media yaitu dosen dan 2 orang reviewer ahli materi yaitu dosen ahli materi. Penelitian dilaksanakan di Penelitian dilaksanakan di SMK Swasta Imelda Medan Jl. Bilal No.24, Kecamatan Medan Timur, Kota Medan, Sumatera Utara 20239, Tahun Ajaran 2019/2020 Kelas XI Jurusan Teknik Jaringan Tenaga Listrik. Variabel dan Sampel Penelitian

Variabel penelitian ini adalah pengembangan media pembelajaran pada Mata Pelajaran Instalasi Motor Listrik. Sedangkan sampel penelitan melibatkan 30 orang siswa kelas XI TITL SMK Swasta Imelda Medan. 


\section{HASIL DAN PEMBAHASAN}

Peneliti merancang media pembelajaran yang diajukan kepada siswa SMK Swasta Imelda Medan dalam bentuk aplikasi android. Media pembelajan ini dibangun dalam bentuk aplikasi android bertujuan untuk mempermudah siswa dalam belajar dimana dapat digunakan dimanapun dan kapanpun. Hal ini mendorong siswa untuk menggunakan waktu belajar selain di sekolah.

Dalam perancangan media pembelajaran ini terdapat kriteria yang menjadi penelitian utama, yaitu: (1) mudah digunakan, (2) memiliki tampilan yang menarik, (3) dapat dioperasikan dimanapun, (4) sesuai dengan kebutuhan, dan (5) mudah dipahami

Menu dalam media pembelajaran mobile learning berbasis android ini terdiri dari: (1) Materi, (2) Quiz, (3) Video, (4) Petunjuk Penggunaan, dan (5) Penulis. Menu materi berisikan informasi terkait dengan pembelajaran pada Instalasi Motor Listrik. Menu quiz berisikan latihan soal-soal latihan untuk mengukur pemahaman siswa tentang materi yang disajikan. Menu video berisikan video dari materi pembelajaran. Menu petunjuk merupakan menu yang berisikan petunjuk penggunaan media pembelajaran.

Menu penulis berisikan tentang profil singkat pembuat media pembelajaran dengan tujuan untuk menunjukkan identitas pembuat serta sebagai originalitas dari produk tersebut. Pencapaian tujuan pembelajaran yang sesuai dengan kurikulum harus dilakukan dengan benar dan baik. Tombol-tombol penunjang dan tombol-tombol utam pada media harus dipastikan memiliki peruntukan yang tepat. Adapun tampilan menu dalam media pembelajaran ini terdiri dari: (1) Slash Screen Slash screen merupakan tampilan awal saat aplikasi dijalankan. Tampilan ini hanya muncul beberapa detik saja. Pada bagian pertama muncul logo Universitas Negeri Medan dengan keterangan program studi pendidikan, logo aplikasi dengan nama aplikasi "Instalasi Motor Listrik" dengan penjelasan aplikasi ini digunakan untuk siswa kelas XI SMK Teknik Instalasi Tenaga Listrik serta nama penulis. Gambar Merupakan tampilan slash screen

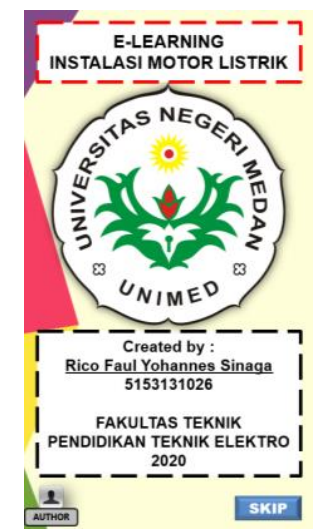

Gambar 1 Tampilan Slash Screean

(2) Beranda, Beranda merupakan tampilan awal dari aplikasi yang berisikan menu-menu yang ada pada aplikasi pembelajaran. Terdapat 5 pilihan menu pada aplikasi ini yaitu: (1) Materi, (2) Quiz, (3) Video, (4) Petunjuk Penggunaan, (5) Penulis. Gambar Merupakan tampilan beranda.

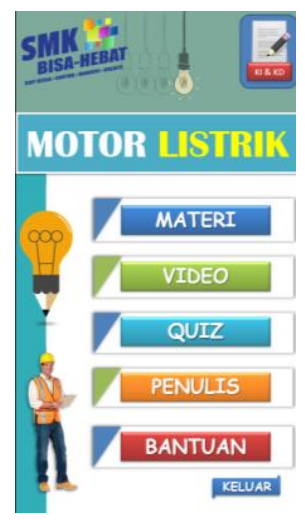

Gambar 2 Tampilan Menu Beranda 
(3) Menu Materi Menu materi merupakan menu yang berisikan informasi terkait isi dari setiap materi yang disajikan. Dalam menu materi Instalasi Motor Listrik ini disajikan 3 pilihan sub menu, yaitu: (1) Pengertian, (2) Prinsip Kerja Komponen Pengendali, (3) Macam - macam Pengendali Motor Listrik (4) Diagram Kendali Elektromagnetik.

Adapun tampilan menu materi dapat dilihat pada gambar berikut :

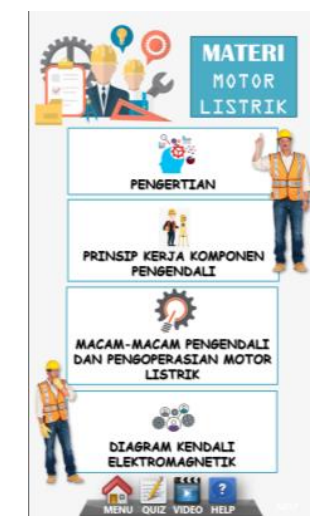

Gambar 3 Tampilan Menu Materi

(4) Menu KI/KD Menu KI/KD berisikan deskripsi kompetensi inti dan indikator yang harus dicapai oleh peserta didik. Pada sisi kiri tampilan terdapat beberapa pilihan menu yang dapat dipilih sesuai dengan Kebutuhan.

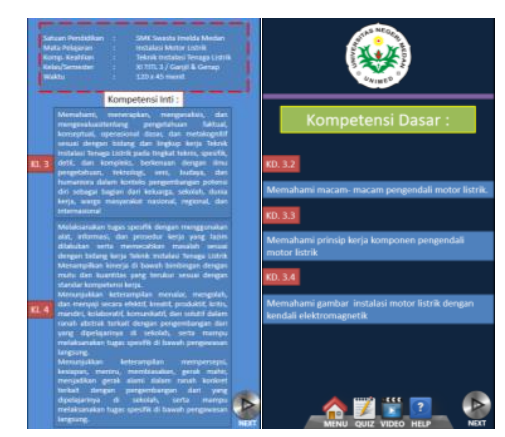

Gambar 4 Tampilan Menu KI dan KD

(5) Menu Quiz Menu quiz dibangun untuk mengukur seberapa besar pemahaman siswa terhadap materi yang disajikan. Menu ini berisikan soal-soal latihan untuk mengukur tingkat pemahaman siswa dalam menguasai materi yang telah dipelajari. Pada tampilan akhir menu quiz akan menujukkan skor/nilai yang telah dikerjakan oleh pengguna. Adapun tampilan menu quiz dapat dilihat pada gambar berikut :

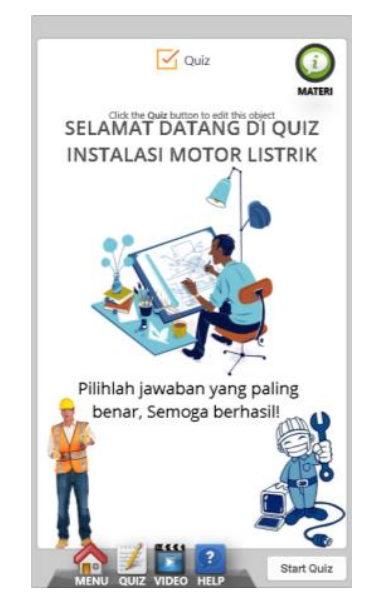

Gambar 5 Tampilan Menu Quiz 
(6) Menu Video Menu video merupakan menu yang berisikan video pembelajarn yang berkaitan dengan materi yang disajikan. Adapun tampilan menu video dapat dilihat pada gambar berikut :

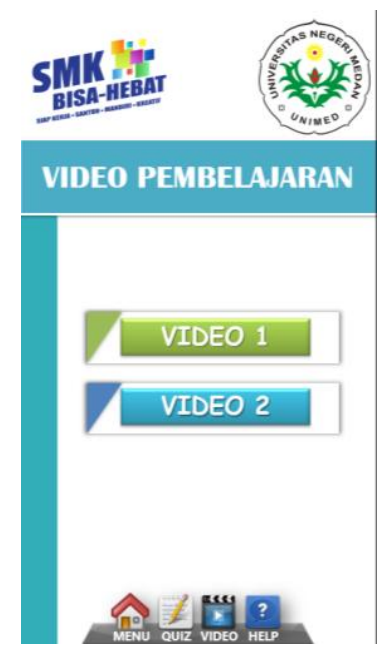

Gambar 6 Tampilan Menu Video

(7) Menu Petunjuk Menu petunjuk berisikan arahan atau langkah-langkah dalam menggunakan aplikasi pembelajaran ini. Adapun tampilan menu petunjuk dapat dilihat pada gambar berikut :

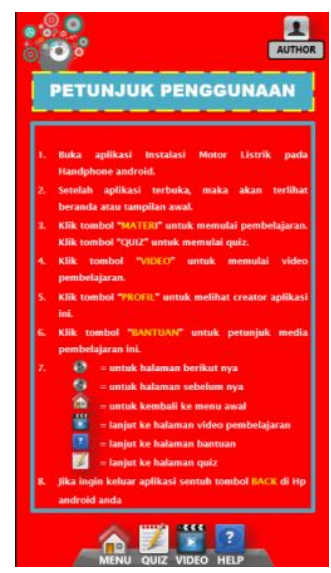

Gambar 7 Tampilan Menu Petunjuk

(8) Menu Penulis, Menu ini berisikan tentang profil singkat pembuat media pembelajaran dengan tujuan untuk menunjukkan identitas pembuat serta sebagai originalitas dari produk tersebut. Adapun tampilan menu penulis dapat dilihat pada gambar berikut :

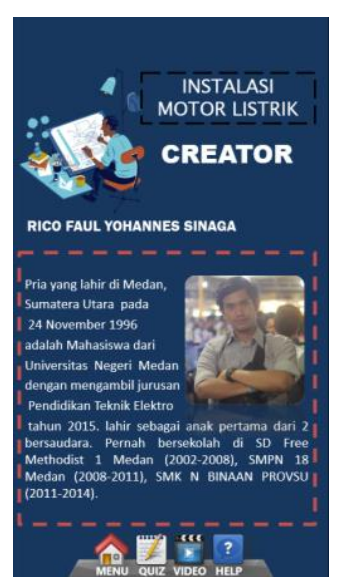

Gambar 8 Tampilan Menu Penulis 
(A) Validasi oleh Ahli Media Aplikasi pembelajaran berbasis android yang dibuat, diperiksa kelayakannya sebagai media pembelajaran oleh ahli media dengan menyertakan angket penilaian. Hasil penilaian ini diakumulasi dan ditampilkan dalam bentuk grafik yang memuat aspek-aspek yang merupakan kunci penilaian. Berikut ini adalah hasil validasi ahli media pertama yaitu Fahmi Syahputra, S,Kom., M.Kom, dan ahli media yang kedua yaitu Reni Rahmadani, S.Kom., M.Kom yang ditunjukkan pada diagram.

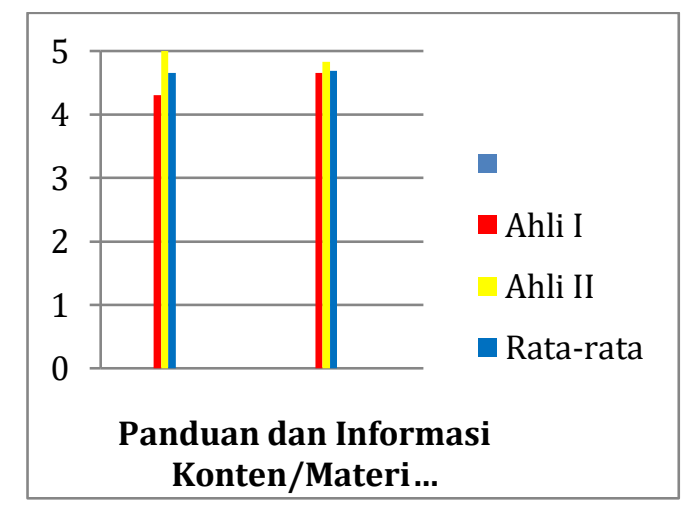

Gambar 9 Grafik Penilaian Ahli Media

Hasil validasi media oleh ahli media diketahui bahwa media mendapatkan rata-rata penilaian pada indikator Panduan Informasi sebesar 4,65 (Sangat Baik). Indikator Konten/Materi Multimedia 4,72 (Sangat Baik). Dan bila dirata-ratakan secara keseluruhan mendapatkan nilai 4,68 dan dapat dinyatakan "Sangat Layak". (B) Validasi oleh Ahli Materi Media pembelajaran berbasis aplikasi android dilakukan uji materi oleh ahli materi pertama Drs. Panahatan Sitorus, S.T., M.Pd, dan Dr. Adi Sutopo, M.Pd., M.T dengan menyertakan angket penilaian. Hasil penialain diakumulasikan dan ditampilkan dalam bentuk grafik yang memuat aspek-aspek yang merupakan kunci penialaian.berikut ini hasil penilaian ahli media yang ditunjukkan pada diagram :

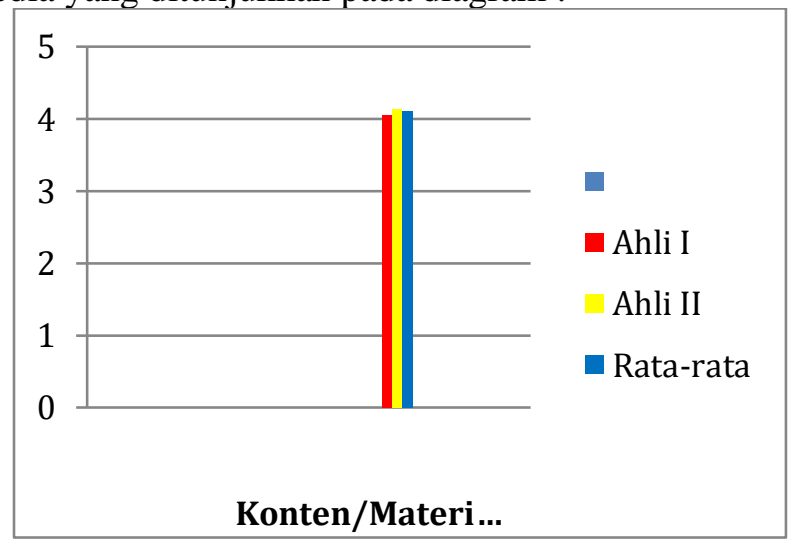

Gambar 10 Grafik Penilaian Ahli Materi

Hasil validasi media oleh ahli materi diketahui bahwa media mendapatkan. Konten/Materi Multimedia sebesar 4,16 (Sangat Baik). Dan bila dirata-ratakan secara keseluruhan mendapatkan nilai 4,16 dan dapat dinyatakan "Layak" (E) Uji Coba Lapangan Sehubungan dengan kondisi pandemi CoVid-19 dan anjuran Pemerintah untuk melakukan kegiatan pembelajaran dirumah, maka kegiatan penelitian/uji coba media pembelajaran terhadap peserta didik kelas XI TITL SMK Swasta Imelda Medan tidak dapat dilakukan. Tetapi sesuai dengan tujuan penelitian yaitu untuk mengetahui kelayakan media pembelajaran mobile learning berbasis android dengan Ispring Suite, pada tahap pengembangan (develop) telah dilakukan validasi oleh ahli materi dan ahli media untuk mengetahui kelayakan media pembelajaran dan tujuan penelitian telah tercapai dimana media pembelajaran yang dikembangkan telah diketahui sejauh mana kelayakannya untuk diterapkan dalam proses pembelajaran. (F) Pembahasan 
Penelitian ini diangkat dari permasalahan karena media pembelajaran yang digunakan oleh guru mata pelajaran berupa buku PLN dan elektronik yang di download siswa yang hanya menampilkan tulisan dan sedikit gambar, sehingga siswa cenderung bosan dalam proses pembelajaran Instalasi Motor Listrik. Metode yang digunakan pada penelitian ini adalah metode Research and Development (R\&D) dengan model ADDIE sebagai desain pembelajarannya. Adapun langkah-langkah pada tahapan penelitian model ADDIE adalah analisis, desain, pengembangan, implementasi, dan evaluasi. Hal ini sesuai dengan tujuan penelitian yaitu untuk dapat mengembangkan media pembelajaran mobile learning berbasis android dengan Ispring Suite pada mata pelajaran Instalasi Motor Listrik kelas XI TITL SMK Swasta Imelda Medan. Media pembelajaran mobile learning berbasis android ini berisikan Menu yang terdiri dari: (1) Materi, (2) Quiz, (3) Video, (4) Petunjuk Penggunaan, (5) Penulis, dan (6) KI \& KD. Menu materi berisikan informasi terkait dengan pembelajaran pada Instalasi Motor Listrik. Menu quiz berisikan latihan soal-soal latihan untuk mengukur pemahaman siswa tentang materi yang disajikan. Menu video berisikan video dari materi pembelajaran. Menu petunjuk merupakan menu yang berisikan petunjuk penggunaan media pembelajaran. Menu penulis berisikan tentang profil singkat pembuat media pembelajaran dengan tujuan untuk menunjukkan identitas pembuat serta sebagai originalitas dari produk tersebut, dan menu KI \& KD di tujukan untuk membatasi pembahasan dari media pembelajaran.

Media pembelajaran mobile learning berbasis android yang dibuat, diperiksa kelayakannya sebagai media pembelajaran dengan menyertakan angket penilaian. Angket penilaian yang digunakan dalam penelitian ini, yaitu angket validasi oleh ahli media pembelajaran (dosen), angket validasi untuk ahli materi (dosen dan guru).

Validator ahli media antara lain Fahmi Syahputra, S,Kom., M.Kom, dan Reni Rahmadani, S.Kom., M.Kom, sedangkan validator ahli materi antara lain Drs. Panahatan Sitorus, S.T., M.Pd dan Dr. Adi Sutopo, M.Pd., M.T dengan menggunakan instrumen penelitian yang diadaptasi dari Sriadhi (2018). Hasil validasi dari ahli materi dan ahli media menunjukkan bahwa media pembelajaran mobile learning berbasis android dengan ispring suite layak digunakan/diterapkan dengan sedikit revisi dalam pembelajaran Instalasi Motor Listrik kelas XI TITL SMK Swasta Imelda Medan dengan dibuktikan pada penjelasan dibawah ini.

Berdasarkan data validasi yang diisi oleh ahli media dan ahli materi sebagai Validator, maka media pembelajaran ini dinyatakan memenuhi persyaratan dan layak digunakan sebagai pembelajaran dengan dibuktikan dengan nilai skor 4,72 dikategorikan "Sangat Layak" dari ahli media dan skor 4,16 dikategorikan "Layak" dari ahli materi.

Produk yang telah dikambangkan tidak dilakukan uji coba produk kepada peserta didik dikarenakan kondisi pandemi CoVid-19 dan anjuran Pemerintah untuk melakukan kegiatan pembelajaran dirumah. Produk telah divalidasi oleh ahli media dan ahli materi untuk diuji kelayakannya dan penelitian hanya dilakukan sampai pada tahap pengembangan (develop) sesuai dengan tujuan penelitian, yaitu untuk mengetahui kelayakan dari media pembelajaran mobile learning berbasis android dengan Ispring Suite.

\section{SIMPULAN}

Simpulan Berdasarkan data hasil penelitian dan pembahasan yang telah di uraikan maka dapat di simpulkan bahwa: Pengembangan media pembelajaran mobile learning berbasis android menggunakan metode penelitian Research and Development (R\&D) dengan model ADDIE sebagai desain pembelajarannya. Adapun langkah-langkah pada tahapan penelitian model ADDIE adalah analisis, desain, pengembangan, implementasi, dan evaluasi. Hal ini sesuai dengan tujuan penelitian yaitu untuk dapat mengembangkan media pembelajaran mobile learning berbasis android dengan Ispring Suite dalam mata pelajaran Instalasi Motor Listrik kelas XI TITL SMK Swasta Imelda Medan. Berdasarkan data validasi yang diisi oleh ahli media dan ahli materi sebagai Validator, maka media pembelajaran ini dinyatakan memenuhi persyaratan dan layak digunakan sebagai pembelajaran dengan dibuktikan dengan nilai skor 4,72 (Sangat Layak) dari ahli media dan skor 4,16 ( Layak) dari ahli materi. (B). Saran Berdasarkan hasil penelitian, pembahasan dan kesimpulan di atas, maka saran yang dapat diberikan pada penelitian ini adalah : Masa kini sarana teknologi berupa smartphone telah memadai serta hampir semua siswa sudah memiliki yang dinamakan smartphone, guru hendaknya menggunakan media pembelajaran mobile learning berbasis android untuk meningkatkan motivasi belajar siswa serta agar siswa bisa belajar secara praktis dimanapun dan kapanpun, ditambah lagi dengan ada nya pandemi saat ini. Mengharuskan guru untuk melakukan pembelajaran secara online atau daring. Dengan ada nya penelitian ini, diharapkan dapat menjadi inspirasi untuk guru di seluruh indonesia. Di masa pandemi ini Guru disekolah dituntut dan harus mengembangkan kreativitasnya dalam membuat media pembelajaran 
untuk siswa dan lebih memanfaatkan media pembelajaran, baik itu video edukatif, animasi, media pembelajaran e-learning, maupun media pembelajaran mobile learning namun tetap dipantau dalam proses pembelajarannya. (PTK) atau Penelitian Kuasi Eksperimen.

\section{DAFTAR PUSTAKA}

Baharuddin. (2017). Interactive Courseware For Supporting Learners Competency in Practical Skills 8. Turkish Online Journal of Educational Techonology.

Baharuddin. (2017). Pengembangan Media Pembelajaran Interaktif SMK Terhadap Efektif dan Efisiensi Pembelajaran. Teknologi Informasi dan Komunikasi dalam Pendidikan. Vol 4 No. 1, 27-28.

Baharuddin. (2017). The Development Of Computer-Based Learning Media At A Vocational High School. Geomate Journal.

Baharuddin, d. (2018). Dilemma Between Applaying Coherent Principle and Signaling Principles In Interactive Learning Media. The Open Psychology.

Developer, G. (2016, December). Android Developer Fundamentals Course. p. 1.

Miarso, Y. (2009). Menyemahi Benih Teknologi Pendidikan. Jakarta: PRENADA MEDIA GROUP.

Mulyatiningsih, E. (2014). Metode Penelitian Terapan Bidang Pendidikan. Bandung: ALFABETA, cv.

Rahmelia, L. (2017). Perancangan Mobile Learning Berbasis Android pada Mata Kuliah Sistem Operasi di STMIK Indonesia Padang. Jurnal Informatika Vol 11, No. 2, 2.

Rusman. (2013). Belajar dan Pembelajaran Berbasis Komputer. Bandung: ALFABETA, cv.

Sadiman, A. S. (2009). Media Pendidikan. Jakarta: PT. RAJAGRAFINDO PERSADA.

Setyosari, P. (2013). Metode Penelitian Pendidikan dan Pengembangan. Jakarta: KENCANA.

Sudaryono. (2013). Pengembangan Instrumen Penelitian Pendidikan. Yogyakarta: GRAHA ILMU.

Wikipedia. (2019, Januari 03). Retrieved Desember 2018, from Google: https://id.wikipedia.org/wiki/Android_(sistem_operasi)

Ispring. (2019, Oktober 29). Retrieved Maret 2020, from Google :

https://ispringindonesia.com/tag/aplikasi-ispring/

Badan Standarisasi Nasional. (2002). Persyaratan Umum Instalasi Listrik 2000, Jakarta : Yayasan Puil

Direktorat Pembinaan Sekolah Menengah kejuruan. (2014). Instalasi Motor Listrik, Jakarta

Munthe, Brayan. (2009)., Kontrol Magnetik, PPPPTK BMTI Bandung,

Pembelajaran. Jakarta: Kencana

Yasaratodo, W. (2013). Profesi Kependidikan. Medan: Unimed Press Universitas Negeri Medan 